\title{
Development of Highly Specific Enzyme Immunoassay for Monitoring Serum Digitoxin Level in Patients
}

\author{
Yasuhiko Higashi, Yukari Ikeda, Mayumi Douno, Youichi Fujii \\ Department of Analytical Chemistry, Faculty of Pharmaceutical Sciences, Hokuriku University, Kanazawa, Japan \\ Email: y-higashi@hokuriku-u.ac.jp
}

Received 9 March 2016; accepted 4 June 2016; published 7 June 2016

Copyright (C) 2016 by authors and Scientific Research Publishing Inc.

This work is licensed under the Creative Commons Attribution International License (CC BY).

http://creativecommons.org/licenses/by/4.0/

c. (i) Open Access

\section{Abstract}

We previously developed radioimmunoassays (RIAs) for digitoxin and digoxin using antisera raised against digitoxin 3'-hemisuccinate-bovine serum albumin and digoxin 3 '-hemisuccinate-bovine serum albumin conjugates, respectively. Very recently, we converted the RIA for digoxin to an enzyme immunoassay (EIA) system. Here, we aimed to convert the RIA for digitoxin to an EIA suitable for measuring serum digitoxin level in patients, using digitoxin 3 '-hemisuccinate- $\beta$-D-galactosidase as an enzyme-labeled antigen. The developed EIA showed a quantification range of 1 to $70 \mathrm{ng} / \mathrm{mL}$ and exhibited high specificity for digitoxin, with low cross-reactivity to digitoxin metabolites. Compared with a commercial anti-digitoxin antiserum clinically used to monitor serum digitoxin level in patients, our antiserum showed much higher specificity for intact digitoxin. Intra- and inter-assay variations were less than $10.0 \%$ and $8.5 \%$, respectively. Recovery was within the range of $93.7 \%$ $107.5 \%$. Mean digitoxin concentrations measured in serum samples $(n=26)$ from digitoxin-treated patients by EIA using our new antiserum and the commercial anti-digitoxin antiserum were 11.0 and $13.8 \mathrm{ng} / \mathrm{mL}$, respectively. The present EIA, which is superior to RIA in terms of convenience and disposal of waste materials, is expected to be practically useful for clinical monitoring of intact digitoxin in serum.

\section{Keywords}

Digitoxin, Digitoxin 3'-Hemisuccinate- $\beta$-D-Galactosidase, Digitoxin 3'-Hemisuccinate-Bovine Serum Albumin, Antiserum, Enzyme Immunoassay, Cross-Reactivity

\section{Introduction}

Digitalis glycosides, such as digitoxin and digoxin, are used clinically to treat congestive heart failure and atrial 
fibrillation. Digitoxin is a secondary glycoside in Digitalis purpurea L. Digitoxin can be prescribed even in patients with impaired renal function, since it is mainly metabolized in the liver, whereas digoxin is predominantly eliminated by the kidney. Therapeutic monitoring of digoxin is important, because the effective concentration range in serum is low and narrow (range: 10 to $20 \mathrm{ng} / \mathrm{mL}$ ). Symptoms of digitalis poisoning, such as atrial tachycardia and vomiting, may appear at serum levels over $20 \mathrm{ng} / \mathrm{mL}$. Thus, control of the serum level is critical, and monitoring of digitoxin in patients' serum has generally been performed with immunoassay. The antisera used in immunoassay are mostly produced by immunization with hapten-carrier protein conjugates [1] [2]. Digitoxin differs from digoxin in the absence of a hydroxyl group at the C-12 position, and administered digitoxin is metabolized to digoxin and other products in the body (Figure 1) [3]-[8]. However, the specificity of these immunoassays for intact digitoxin is relatively poor.

To obtain a highly specific antibody, the binding position of the hapten to the carrier protein is critical. Shimada et al. [9] and Thong et al. [10] used conjugates in which the hapten was linked to the carrier protein at the C-12 (or C-17) and C-22 positions of digoxin, respectively. However, these antisera exhibited high cross-reactivity with dihydrodigoxin, one of the metabolites of digoxin. We subsequently prepared digitoxin-bovine serum albumin (BSA) linked at the digitoxose C-3' and C-3" positions for use in radioimmunoassay (RIA) [11] [12]. Antiserum raised against digitoxin 3'-hemisuccinate-BSA (Antiserum-A) showed much higher specificity for intact digitoxin than did commercially available anti-digitoxin antiserum (Antiserum-B). We used these antisera for pharmacokinetic studies of digoxin in rats, and for measuring digoxin and digitoxin levels in human serum by RIA [13]-[17]. However, RIA requires special facilities and involves waste disposal problems. On the other hand, several assay methods for digitoxin in biological samples have been developed using liquid chromatography/

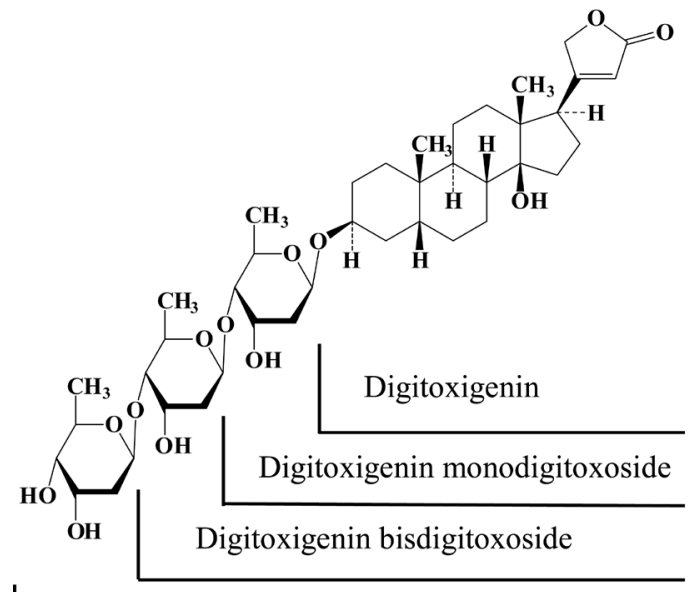

Digoxin

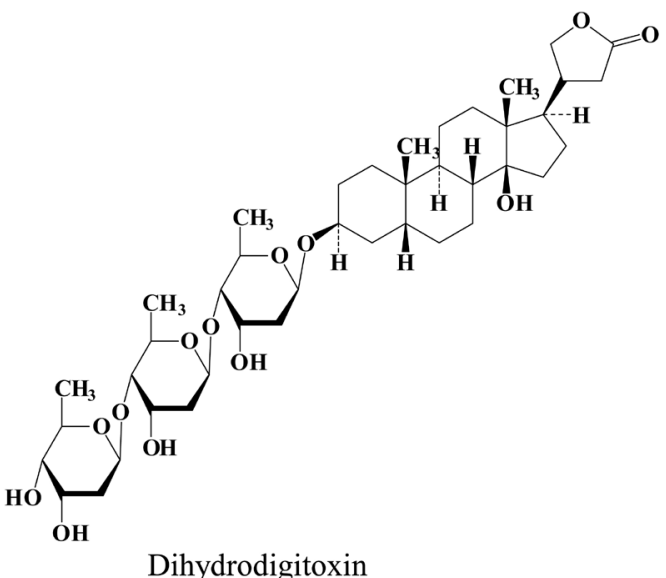

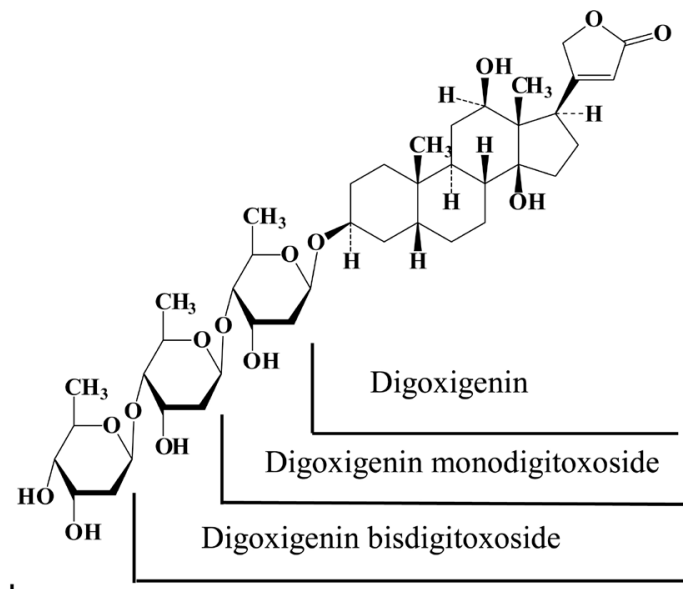

Digoxin

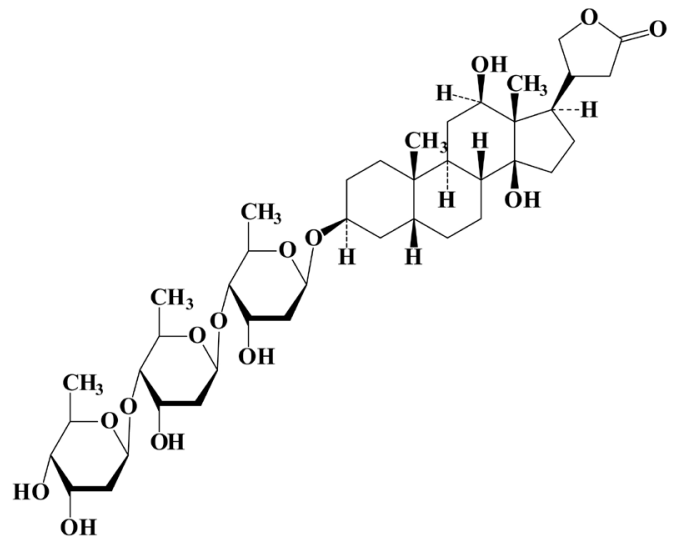

Dihydrodigoxin

Figure 1. Chemical structures of digoxin and its metabolites. 
mass spectrometry [18]-[21], but these techniques are quite complex, and require expensive equipment. Therefore, we set out to develop a convenient EIA system for intact digitoxin.

Very recently, we prepared digoxin 3'-hemisuccinate- $\beta$-D-galactosidase as an enzyme-labeled antigen from digoxin 3'-hemisuccinate $p$-nitrophenyl ester, and established an enzyme immunoassay (EIA) for digoxin [22]. The assay was based on hydrolysis of 4-methylumbelliferyl- $\beta$-D-galactopyranoside as a substrate to generate a fluorescent product (4-methylumbelliferone), and was suitable for precise measurement of digoxin in the range of 0.5 to $2 \mathrm{ng} / \mathrm{mL}$. Here, we aimed to develop a similar EIA for digitoxin, using digitoxin 3'-hemisuccinate- $\beta$ D-galactosidase prepared from digitoxin 3'-hemisuccinate $p$-nitrophenyl ester as an enzyme-labeled antigen. Since the therapeutic level of digitoxin (10 to $20 \mathrm{ng} / \mathrm{mL}$ ) is about 10 -fold higher than the level of digitoxin (0.5 to $2 \mathrm{ng} / \mathrm{mL}$ ), we expected that it would be feasible to use widely available ultraviolet and visible light (UV-Vis) absorption spectrophotometric apparatus to detect visible light absorption of $o$-nitrophenol produced in the enzyme reaction. We compared the digitoxin levels measured with the two EIAs in serum of digitoxin-treated patients, and confirmed that EIA using our Antiserum-A was superior to EIA using Antiserum-B in terms of specificity for intact digitoxin.

\section{Materials and Methods}

\subsection{Materials}

Digitoxin, $\beta$-D-galactosidase (EC 3.2.1.23) from Escherichia coli, and $o$-nitrophenyl- $\beta$-D-galactopyranoside were obtained from Wako Pure Chemical Industries (Osaka, Japan). Digoxin was obtained from Aldrich (Milwaukee, WI, U.S.A.). Spironolactone, BSA (fraction V), anti-rabbit IgG antiserum raised in goat, and anti-digoxin antiserum were from Sigma Chemical Co. (St. Louis, MO, U.S.A.), and dihydrodigitoxin and dihydrodigoxin were from Boehringer Mannheim (Mannheim, Germany). Sephadex G-25 and G-100 were purchased from Pharmacia Fine Chemicals (Uppsala, Sweden). Digitoxigenin, digitoxigenin monodigitoxoside, digitoxigenin bisdigitoxoside, digoxigenin, digoxigenin monodigitoxoside, and digoxigenin bisdigitoxoside were prepared by hydrolysis of digitoxin and digoxin according to the methods of Kaiser and co-workers [23].

\subsection{Preparation of $\beta$-D-Galactosidase-Labeled Antigen (Figure 2)}

Digitoxin 3'-hemisuccinate p-nitrophenyl ester was prepared from digitoxin 3'-hemisuccinate, according to our previous work [16]. Conjugation of $\beta$-D-galactosidase was carried out in the same manner as described previously in connection with our establishment of an EIA for $\beta$-methyldigoxin using anti- $\beta$-methyldigoxin 3'-hemisuccinate-BSA antiserum and for digoxin using anti-digoxin 3'-hemisuccinate-BSA antiserum [22] [24]. Briefly, a solution of digitoxin 3'-hemisuccinate $p$-nitrophenyl ester $(7.0 \mathrm{mg})$ in dioxane $(1.5 \mathrm{~mL})$ was incubated with a solution of $\beta$-D-galactosidase $(2.2 \mathrm{mg}$ ) in $1 \mathrm{~mL}$ of $0.05 \mathrm{~mol} / \mathrm{L}$ phosphate buffer (pH 9.0) for $4 \mathrm{~h}$ at $4^{\circ} \mathrm{C}$. The reaction mixture was chromatographed on a Sephadex G-25 column $(45 \times 1.5 \mathrm{~cm}$ i.d.) with 0.05 $\mathrm{mol} / \mathrm{L}$ phosphate buffer (pH 7.0) as the mobile phase. Fractions (each $2.5 \mathrm{~mL}$ ) representing the main peak of the enzyme activity were combined and further subjected to Sephadex G-100 column $(45 \times 1.5 \mathrm{~cm}$ i.d.) chromatography with $0.05 \mathrm{~mol} / \mathrm{L}$ phosphate buffer $(\mathrm{pH} 7.0)$ as the mobile phase. Fractions representing the main peak of

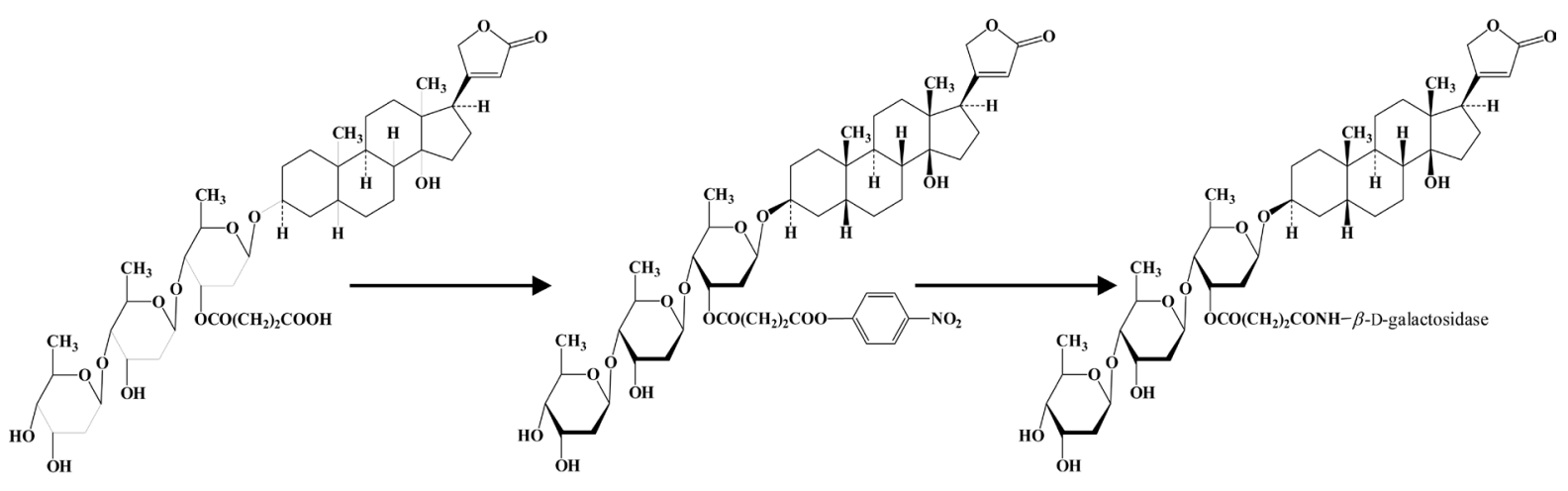

Digitoxin 3'-hemisuccinate

Digitoxin 3'-hemisuccinate $p$-nitorophenyl ester

Digitoxin 3'-hemisuccinate- $\beta$-D-galactosidase

Figure 2. Synthesis of digitoxin 3'hemisuccinate- $\beta$-D-galactosidase. 
the enzyme activity were used as the labeled antigen in EIA. The presence of steroid structure was confirmed by thin-layer chromatography with $\mathrm{CHCl}_{3}-\mathrm{MeOH}-\mathrm{AcOH}\left(90: 10: 0.8\right.$, v/v), using concentrated $\mathrm{H}_{2} \mathrm{SO}_{4}$ spray for detection. The results confirmed the formation of enzyme-labeled antigen (digitoxin 3'-hemisuccinate- $\beta$-D-galactosidase).

\subsection{EIA Procedure}

EIA is based on the principle of competition between enzyme-labeled and unlabeled drugs for an antibody, followed by measurement of the marker enzyme activity of the immunoprecipitate. Phosphate-buffered saline for EIA was adjusted to $\mathrm{pH} 7.3$ by addition of a solution containing $\mathrm{NaH}_{2} \mathrm{PO}_{4}$ (3.9 g), $\mathrm{NaCl}$ (4.5 g), $\mathrm{NaN}_{3}(0.5 \mathrm{~g})$, $\mathrm{MgCl}_{2}(0.005 \mathrm{~g})$, and BSA (0.5 g) in $\mathrm{H}_{2} \mathrm{O}(500 \mathrm{ml})$ to a solution containing $\mathrm{K}_{2} \mathrm{HPO}_{4}(8.7 \mathrm{~g}), \mathrm{NaCl}(9.0 \mathrm{~g}), \mathrm{NaN} 3$ $(1.0 \mathrm{~g}), \mathrm{MgCl}_{2}(0.01 \mathrm{~g})$, and BSA $(1.0 \mathrm{~g})$ in $\mathrm{H}_{2} \mathrm{O}(1000 \mathrm{~mL})$. An aliquot of $0.1 \mathrm{~mL}$ of digitoxin (2.1 to 600 $\mathrm{ng} / \mathrm{mL})$ in phosphate buffer was added to drug-free serum $(0.3 \mathrm{~mL}$, serum digitoxin concentration of 0.7 to 200 $\mathrm{ng} / \mathrm{mL})$. An aliquot of $0.1 \mathrm{~mL}$ of digitoxin-free phosphate buffer was added to an aliquot of patient's serum (0.3 $\mathrm{mL})$. These mixtures were used for the assay. A mixture of sample $(0.4 \mathrm{~mL})$, synthetic enzyme-labeled antigen in phosphate-buffered saline $(0.1 \mathrm{~mL}$, diluted 1:1200), and diluted Antiserum-A (0.1 mL, 1:28800) or Antiserum-B $(0.1 \mathrm{~mL}, 1: 9000)$ was incubated for $4 \mathrm{~h}$ at $4^{\circ} \mathrm{C}$. An aliquot of $0.2 \mathrm{~mL}$ of goat anti-rabbit IgG antiserum $(1.67 \%)$ and $0.1 \mathrm{~mL}$ of normal rabbit serum (1\%) were added, and the mixture was left to stand for $16 \mathrm{~h}$ at $4^{\circ} \mathrm{C}$, and then centrifuged at $1600 \times g$ for $20 \mathrm{~min}$. The supernatant was aspirated, and the immunoprecipitate was washed twice with $1 \mathrm{~mL}$ of phosphate-buffered saline. The activity of enzyme conjugate bound to each tube was measured by the addition of $1 \mathrm{~mL}$ of $o$-nitropheny- $\beta$-D-galactopyranoside $(0.24 \%)$, followed by incubation of the tubes at $37^{\circ} \mathrm{C}$ for $3 \mathrm{~h}$ after pre-incubation with $1 \mathrm{~mL}$ of $10 \%$ ethylene glycol in phosphate-buffered saline solution at $37^{\circ} \mathrm{C}$ for $3 \mathrm{~min}$. The enzyme reaction was stopped by addition of $1 \mathrm{~mL}$ of $\mathrm{Na}_{2} \mathrm{CO}_{3}$ solution $(2 \mathrm{~mol} / \mathrm{L})$ to each tube, and $o$-nitrophenol formed was quantitated by measuring the absorbance at $420 \mathrm{~nm}$ with a UV-Vis absorption spectrophotometer (UV-1200, Shimadzu, Kyoto, Japan).

\subsection{Cross-Reaction Study}

We determined the specificities of Antiserum-A and Antiserum-B by calculating the percentage cross-reactivity with various compounds. Cross-reactivity was determined according to the above-mentioned assay procedure, by comparing the concentrations of digoxin and test compounds necessary for $50 \%$ displacement of the antibody-bound enzyme-labeled digitoxin.

\section{Results and Discussion}

\subsection{Standard Curve}

The standard curve of digitoxin in homologous assay with Antiserum-A is presented in Figure 3. The plot of percent bound fluorescence intensity vs. logarithm of the concentration of non-labeled digitoxin showed a quantification range of 1 to $70 \mathrm{ng} / \mathrm{mL}$. On the other hand, the standard curve of digitoxin using Antiserum-B gave a narrower quantification range of 2 to $40 \mathrm{ng} / \mathrm{mL}$. Thus, Antiserum-A is superior to Antiserum-B in terms of quantification range and lower limit of quantitation.

\subsection{Cross-Reactivity}

The specificities of Antiserum-A and Antiserum-B were assessed by means of cross-reaction assays with various related compounds. The percentage cross-reactivity was calculated at $50 \%$ displacement of the antibody-bound labeled digitoxin, and the results are listed in Table 1. Antiserum-A showed high specificity for digitoxin, exhibiting low cross-reactivity with dihydrodigitoxin (19.3\%), digoxin (6.19\%), digoxigenin bisdigitoxoside (2.05\%), digitoxigenin bisdigitoxoside (1.95\%), and dihydrodigoxin (1.33\%). Further, there was little cross-reactivity with digoxigenin monodigitoxoside $(0.70 \%)$ or digitoxigenin monodigitoxoside $(0.14 \%)$. In contrast, Antiserum-B exhibited considerable cross-reactivity with digitoxigenin (162\%), digitoxigenin bisdigitoxoside (129\%), digitoxigenin monodigitoxoside (54.2\%), and digoxigenin bisdigitoxoside (29.3\%), although it showed low cross-reactivity with digoxin (7.98\%), dihydrodigoxin (6.68\%), digoxigenin (5.11\%), and digoxigenin monodigitoxoside (1.99\%), and had no significant cross-reactivity with dihydrodigoxin (0.09\%). Other 


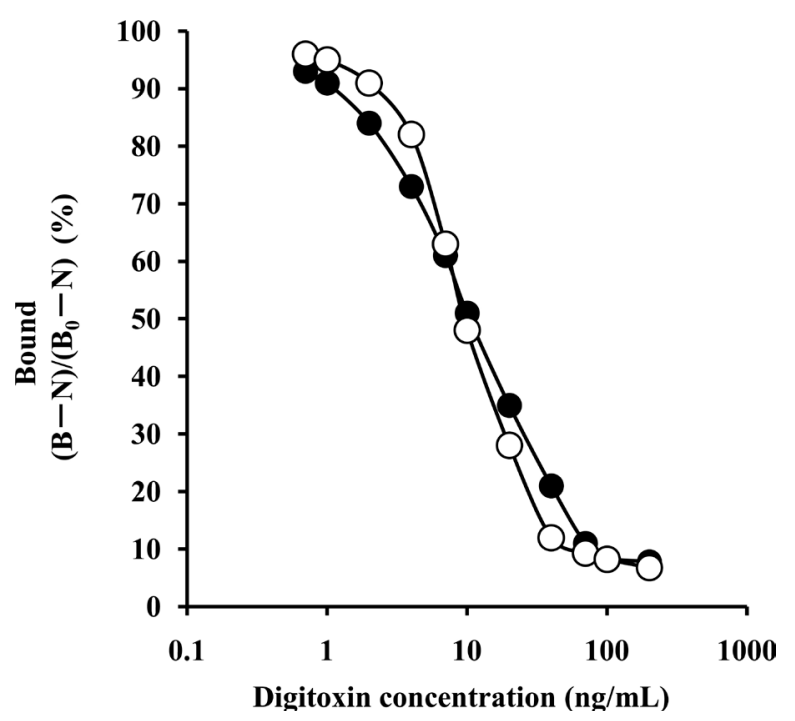

Figure 3. Standard curves of digitoxin obtained by EIA using anti-digitoxin 3'-hemisuccinate-BSA antiserum (Antiserum-A) and commercially available anti-digitoxin antiserum (Antiserum-B). Antiserum-A (•), Antiserum-B (०).

Table 1. Cross-reaction data for EIA with Antiserum-A and, Antiserum-B, and our previous data obtained by RIA.

\begin{tabular}{|c|c|c|c|c|}
\hline & \multicolumn{4}{|c|}{ \% Cross-reactivity (50\%) } \\
\hline & \multicolumn{2}{|c|}{ EIA } & \multicolumn{2}{|c|}{ RIA [12] } \\
\hline & Antiserum-A & Antiserum-B & Antiserum-A & Antiserum-B \\
\hline Digitoxin & 100 & 100 & 100 & 100 \\
\hline Digitoxigenin bisdigitoxoside & $1.95^{*}$ & 129 & 19.0 & 95.9 \\
\hline Digitoxigenin monodigitoxoside & $0.14^{*}$ & 54.2 & 2.1 & 85.8 \\
\hline Digitoxigenin & $<0.05^{*}$ & 162 & 0.10 & 157 \\
\hline Dihydrodigitoxin & 19.3 & 6.68 & 4.1 & 3.5 \\
\hline Digoxin & 6.19 & 7.98 & 1.8 & 10.0 \\
\hline Digoxigenin bisdigitoxoside & $2.05^{*}$ & 29.3 & 0.25 & 8.4 \\
\hline Digoxigenin monodigitoxoside & 0.70 & 1.99 & 0.19 & 5.9 \\
\hline Digoxigenin & $<0.05^{*}$ & 5.11 & 0.01 & 4.7 \\
\hline Dihydrodigoxin & 1.33 & 0.09 & 0.06 & 0.04 \\
\hline Spironolactone & $<0.05$ & $<0.05$ & $<0.01$ & $<0.01$ \\
\hline Digitoxose & $<0.05$ & $<0.05$ & $<0.01$ & $<0.01$ \\
\hline Progesterone & $<0.05$ & $<0.05$ & $<0.01$ & $<0.01$ \\
\hline Testosterone & $<0.05$ & $<0.05$ & $<0.01$ & $<0.01$ \\
\hline Cholesterol & $<0.05$ & $<0.05$ & $<0.01$ & $<0.01$ \\
\hline
\end{tabular}

Values are calculated on a molar basis. ${ }^{*}$ : Remarkable reduction. RIA: Data from our previous paper [12].

compounds tested exhibited negligible cross-reactivity $(<0.05 \%)$ with both antisera. Thus, Antiserum-B showed high cross-reactivity with metabolites formed by successive cleavage of digitoxose residues, being greatly inferior to Antiserum-A for monitoring of intact digitoxin. In our previously developed RIA, Antiserum-A also showed high specificity, exhibiting low or no significant cross-reactivity with various digitoxin metabolites [12]. In contrast, Antiserum-B possessed much lower specificity for digitoxin, exhibiting high levels of cross-reactivity with digitoxin metabolites. In the present EIA, the high specificity of our Antiserum-A observed in RIA was well retained.

\subsection{Validation of EIA}

As shown in Table 2, to investigate the precision of the EIA, we examined the intra- and inter-assay reproducibility $(n=7)$ for human serum spiked at $5,10,20$, and $40 \mathrm{ng} / \mathrm{mL}$ by means of homologous assay using Antiserum-A, which had the highest selectivity for digoxin. The intra-assay coefficient of variation was in the range of $3.8 \%$ to $10.0 \%$, and the recovery was $96.0 \%$ to $107.3 \%$. In the inter-assay study, the range of standard deviation 
was $6.9 \%-8.5 \%$, and the recovery was $93.6 \%-102.0 \%$. These data show that the EIA using digitoxin 3'-hemisuccinate- $\beta$-D-galactosidase and Antiserum-A gave satisfactory precision and accuracy.

\subsection{Interference by Digitoxin Metabolites}

It is well known that digitoxin is metabolized to the bisdigitoxoside, monodigitoxoside, and genin by cleavage of sugar moieties [6]. In addition, digitoxin is metabolized to digoxin and its degradation products by C-12 hydroxylation and to dihydrodigitoxin by reduction of the double bond in the lactone ring [7] [8]. As shown in Table 3, we investigated whether digitoxin metabolites interfered with the assay in human serum. Each metabolite was added to human serum at a ratio of $10 \%$ to digitoxin, and a recovery test was performed. The recovery ratios using Antiserum-A at 5, 10, and $20 \mathrm{ng} / \mathrm{mL}$ were within the range of $109.0 \%-112.4 \%$. In contrast, those using Antiserum-B at 5, 10, and $20 \mathrm{ng} / \mathrm{mL}$ were within the range of $176.0 \%-183.6 \%$. These results indicate that the interference by digitoxin metabolites was significant in the case of Antiserum-B, but was greatly reduced with Antiserum-A.

\subsection{Digitoxin Concentration in Serum of Digoxin-Treated Patients}

Serum samples $(n=26)$ obtained from digitoxin-treated patients were examined by EIA using Antiserum-A, and the assay performance was compared with that of EIA using Antiserum-B (Figure 4). When Antiserum-A was used, the mean digoxin concentration was obtained as $11.0 \mathrm{ng} / \mathrm{mL}$ (range: 1.3 to $19.5 \mathrm{ng} / \mathrm{mL}$ ). When the same samples were measured with Antiserum-B, the mean value of digoxin was $13.8 \mathrm{ng} / \mathrm{mL}$ (range: 3.9 to 28.0 $\mathrm{ng} / \mathrm{mL}$ ). When a straight line passing through the origin of the coordinates was calculated by least squares method, the ratio of concentrations obtained by EIA using Antiserum-A to those using Antiserum-B was 0.7914. We consider that the values obtained using Antiserum-B were higher than those obtained using Antiserum-A because of the greater cross-reactivity of Antiserum-B with digitoxin metabolites, i.e., Antiserum-A measures predominantly intact digitoxin, while Antiserum-B measures both intact digitoxin and its metabolites. The results also suggest that there are marked inter-individual differences between patients with regard to metabolism of digitoxin to form digoxigenin, its mono- and bisdigitoxosides, and dihydrodigoxin. Our previously reported

Table 2. Recovery of digitoxin by EIA using Antiserum-A.

\begin{tabular}{|c|c|c|c|}
\hline \multicolumn{4}{|l|}{ Intra-assay $(n=7)$} \\
\hline Added (ng/mL) & $\begin{array}{l}\text { Measured }(\mathrm{ng} / \mathrm{mL}) \\
\text { Mean } \pm \text { S.D. }\end{array}$ & C.V. (\%) & Recovery (\%) \\
\hline 5 & $5.20 \pm 0.20$ & 3.8 & 104.0 \\
\hline 10 & $9.70 \pm 0.39$ & 4.0 & 97.0 \\
\hline 20 & $19.2 \pm 1.7$ & 8.9 & 96.0 \\
\hline 40 & $42.9 \pm 4.3$ & 10.0 & 107.3 \\
\hline \multicolumn{4}{|l|}{ Intra-assay $(n=7)$} \\
\hline Added (ng/mL) & $\begin{array}{l}\text { Measured }(\mathrm{ng} / \mathrm{mL}) \\
\text { Mean } \pm \text { S.D. }\end{array}$ & C.V. (\%) & Recovery (\%) \\
\hline 5 & $4.68 \pm 0.40$ & 8.5 & 93.6 \\
\hline 10 & $9.74 \pm 0.67$ & 6.9 & 97.4 \\
\hline 20 & $20.4 \pm 1.6$ & 7.8 & 102.0 \\
\hline 40 & $40.8 \pm 3.1$ & 7.6 & 102.0 \\
\hline
\end{tabular}

Table 3. Comparison of interference by digitoxin metabolites in EIA of digitoxin using Antisrum-A and Antiserum-B.

\begin{tabular}{|c|c|c|c|c|c|c|}
\hline \multirow[b]{2}{*}{ Added } & \multicolumn{3}{|c|}{ Antiserum-A } & \multicolumn{3}{|c|}{ Antiserum-B } \\
\hline & $\begin{array}{l}\text { Measured }(n g / m L) \\
\text { Mean } \pm \text { S.D. }(n=7)\end{array}$ & $\begin{array}{l}\text { C.V. } \\
(\%)\end{array}$ & $\begin{array}{l}\text { Recovery } \\
\text { (\%) }\end{array}$ & $\begin{array}{l}\text { Measured }(n g / m L) \\
\text { Mean } \pm \text { S.D. }(n=7)\end{array}$ & $\begin{array}{l}\text { C.V. } \\
(\%)\end{array}$ & $\begin{array}{c}\text { Recovery } \\
\text { (\%) }\end{array}$ \\
\hline Digitoxin (5 ng/mL) + Metabolites (each 0.5 ng/mL) & $5.62 \pm 0.41$ & 7.3 & 112.4 & $9.18 \pm 0.77$ & 8.4 & 183.6 \\
\hline Digitoxin $(10$ ng/mL) + Metabolites (each 1 ng/mL) & $11.1 \pm 0.8$ & 7.2 & 111.0 & $17.8 \pm 1.4$ & 7.9 & 178.0 \\
\hline Digitoxin (20 ng/mL) + Metabolites (each 2 ng/mL) & $21.8 \pm 1.8$ & 8.3 & 109.0 & $35.2 \pm 2.6$ & 7.4 & 176.0 \\
\hline
\end{tabular}

Metabolites: digitoxigenin bisdigitoxoside, digitoxigenin monodigitoxoside, digitoxigenin, dihydrodigitoxin, digoxin, digoxigenin bisdigitoxoside, digoxigenin monodigitoxoside, digoxigenin, and dihydrodigoxin. 


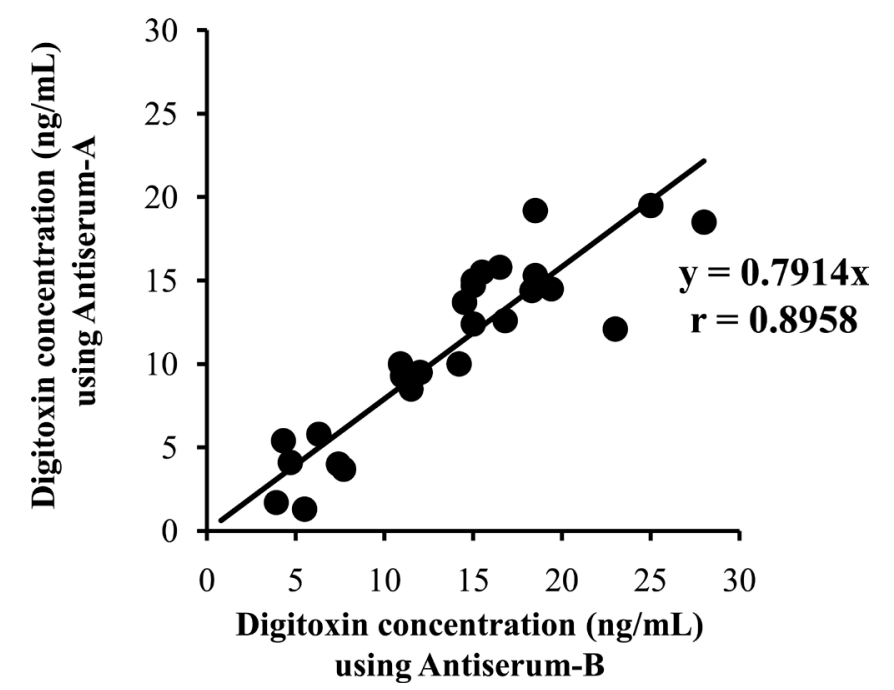

Figure 4. Comparison of digitoxin concentrations in serum from digitoxin-treated patients, measured by using Antisrum-A and Antiserum-B.

EIA for digoxin using a specific antiserum produced in our laboratory showed that the ratio of the concentrations obtained by EIA using this antiserum to those using commercially available antiserum for digoxin was 0.9232. From the above data, it is considered that the present EIA using Antiserum-A is less susceptible to interference by digitoxin metabolites and related compounds. This is important, because digitoxin is readily metabolized in the body.

\section{Conclusion}

We have established and validated an EIA with high specificity for digitoxin over its metabolites by using digitoxin 3'-hemisuccinate- $\beta$-D-galactosidase as an enzyme-labeled antigen and Antiserum-A as a specific antiserum, based on our previously established RIAs for digoxin and digitoxin. The developed EIA measures intact digitoxin with high specificity, and should be suitable for pharmacokinetic studies and therapeutic monitoring. Antiserum-A may also be a candidate for treatment of digitoxin overdose.

\section{References}

[1] Butler Jr., V.P. and Chen, J.P. (1967) Digoxin-Specific Antibodies. Proceedings of the National Academy of Science, USA, 57, 71-78. http://dx.doi.org/10.1073/pnas.57.1.71

[2] Smith, T.W., Butler, Jr., V.P. and Haber, E. (1970) Characterization of Antibodies of High Affinity and Specificity for the Digitalis Glycoside Digoxin. Biochemistry, 9, 331-337. http://dx.doi.org/10.1021/bi00804a020

[3] Valdes Jr., R., Brown, B.A. and Graves, S.W. (1984) Variable Cross-Reactivity of Digoxin Metabolites in Digoxin Immunoassays. American Journal of Clinical Pathology, 82, 210-213. http://dx.doi.org/10.1093/ajcp/82.2.210

[4] Soldin, S.J. (1986) Digoxin-Issues and Controversies. Clinical Chemistry, 32, 5-12.

[5] Miller, J.J., Straub Jr., R.W. and Valdes Jr., R. (1994) Digoxin Immunoassay with Cross-Reactivity of Digoxin Metabolites Proportional to Their Biological Activity. Clinical Chemistry, 40, 1898-1903.

[6] Graves, P.E., Perrier, D. and Marcus, F.I. (1983) Quantitation of Digitoxin and the Bis- and Monodigitoxosides of Digitoxigenin in Serum. Journal of Chromatography, 278, 397-405. http://dx.doi.org/10.1016/S0378-4347(00)84799-4

[7] Santos, S.R., Kirch, W. and Ohnhaus, E.E. (1987) Simultaneous Analysis of Digitoxin and Its Clinically Relevant Metabolites Using High-Performance Liquid Chromatography and Radioimmunoassay. Journal of Chromatography, 419, 155-164. http://dx.doi.org/10.1016/0378-4347(87)80274-8

[8] Bodem, G. and Unruh, E.V. (1979) Enhanced Transformation of Digitoxin to Dihydrodigitoxin in Humans with Renal Failure. Journal of Clinical Pharmacology, 19, 195-199. http://dx.doi.org/10.1002/j.1552-4604.1979.tb01651.x

[9] Shimada, K., Mizusawa, S., Ohkubo, T. and Nambara, T. (1984) Preparation of Specific Antisera to Digoxin Using Hapten-[C-17]- and [C-12]-Bovine Serum Albumin Conjugates. Chemical and Pharmaceutical Bulletin, 32, 23012306. http://dx.doi.org/10.1248/cpb.32.2301 
[10] Thong, B., Soldin, S.J. and Lingwood, C.A. (1985) Lack of Specificity of Current Anti-Digoxin Antibodies, and Preparation of a New, Specific Polyclonal Antibody That Recognizes the Carbohydrate Moiety of Digoxin. Clinical Chemistry, 31, 1625-1631.

[11] Fujii, Y., Ikeda, Y., Fujii, M. and Yamazaki M. (1994) Preparation and Antigenic Properties of Digitoxin-Bovine Serum Albumin Conjugates Linked at the Digitoxose C-3' and C-3'’ Positions. Biological and Pharmaceutical Bulletin, 17, 467-471. http://dx.doi.org/10.1248/bpb.17.467

[12] Ikeda, Y., Fujii, M., Yamazaki, M. and Fujii, Y. (2001) Measurement of Serum Digitoxin in Patients by Radioimmunoassay Using Specific Serum. Clinica Chimica Acta, 314, 245-247. http://dx.doi.org/10.1016/S0009-8981(01)00635-0

[13] Ikeda, Y. and Fujii, Y. (2000) Preparation of Specific Antisera to Digoxin by Using Digoxin C-3' and C-3’' Hemisuccinate-Bovine Serum Albumin Conjugates. Biological and Pharmaceutical Bulletin, 23, 906-910. http://dx.doi.org/10.1248/bpb.23.906

[14] Fujii, Y., Ikeda, Y. and Yamazaki, M. (1994) Highly Specific Anti-Digoxin Antiserum from Immunization with Digoxin 3'-Hemisuccinate-Bovine Serum Albumin Conjugate. Clinical Chemistry, 40, 172-173.

[15] Higashi, Y., Ikeda, Y., Yamamoto, R., Yamashiro, M. and Fujii Y. (2005) Pharmacokinetic Interaction with Digoxin and Glucocorticoids in Rats Detected by Radio-Immunoassay Using a Novel Specific Antiserum. Life Science, 77, 1055-1067. http://dx.doi.org/10.1016/j.lfs.2005.03.003

[16] Ikeda, Y., Araki, T., Takimoto, H. and Fujii, Y. (2002) Development of Radioimmunoassay for Measurement of Serum Digoxin in Digitalized Patients Using Novel Anti-Digoxin Antiserum. Biological and Pharmaceutical Bulletin, 25, 422-425. http://dx.doi.org/10.1248/bpb.25.422

[17] Ikeda, Y. and Fujii Y. (2005) Properties of Novel Anti-Digoxin Antisera in Radioimmunoassay Using Homologous and Site Heterologous Tritium-Labeled Antigens Involving a $\left[{ }^{3} \mathrm{H}\right]$-Leucine Moiety. Biological and Pharmaceutical Bulletin, 28, 340-343. http://dx.doi.org/10.1248/bpb.28.340

[18] Guan, F., Ishii, A., Seno, H., Watanabe-Suzuki, K., Kumazawa, T. and Suzuki, O. (1999) Identification and Quantification of Cardiac Glycosides in Blood and Urine Samples by HPLC/MS/MS. Analytical Chemistry, 71, 4034-4043. http://dx.doi.org/10.1021/ac990268c

[19] Yao, M., Zhang, H., Chong, S., Zhu, M. and Morrison, R.A. (2003) A Rapid and Sensitive LC/MS/MS Assay for Quantitative Determination of Digitoxin in Rat Plasma. Journal of Pharmaceutical and Biomedical Analysis, 32, 1189-1197. http://dx.doi.org/10.1016/S0731-7085(03)00050-5

[20] Kaiser, P., Kramer, U., Meissner, D., Kress, M., Wood, W.G. and Reinauer, H. (2003) Determination of the Cardiac Glycosides Digoxin and Digitoxin by Liquid Chromatography Combined with Isotope-Dilution Mass Spectrometry (LC-IDMS)_A Candidate Reference Measurement Procedure. Clinical Laboratory, 49, 329-343.

[21] Mitamura, K., Horikawa, A., Nagahara, A., Shimada, K. and Fujii, Y. (2005) Determination of Digitoxin in Human Serum Using Stable Isotope Diluted Liquid Chromatography/Electrospray Ionization-Tandem Mass Spectrometry. Journal of Liquid Chromatography \& Related Technologies, 28, 2839-2848. http://dx.doi.org/10.1080/10826070500269869

[22] Higashi, Y., Ikeda, Y., Yamamoto, N. and Fujii, Y. (2015) Establishment of a Highly Specific Enzyme Immunoassay for Digoxin in Human Serum. Jacobs Journal of Nanomedicine and Nanotechnology, 1, 1-6.

[23] Haack, E., Kaiser, F. and Spingler, H. (1957) Digoxigenin Mono- and Bis-Digitoxoside, Two New Glycoside of Digitalis Lanata. Naturwissenschaften, 44, 633-634. http://dx.doi.org/10.1007/BF01177965

[24] Higashi, Y., Watanabe, N., Sasaki, T. and Fujii, Y. (2002) Establishment of Enzyme Immunoassay for Measuring $\beta$ Methyldigoxin Levels in Human Serum by Specific Antiserum. Biological and Pharmaceutical Bulletin, 25, 12511257. http://dx.doi.org/10.1248/bpb.25.1251 